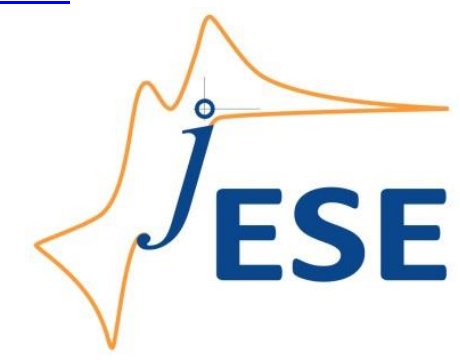

Open Access : : ISSN 1847-9286

www.jESE-online.org

Original scientific paper

\title{
Comparative study between synthetic and dairy wastewaters in single chamber microbial fuel cell for power generation
}

\author{
Payel Choudhury ${ }^{1, \bowtie}$, Ria Majumdar², Tarun Kanti Bandyopadhyaya ${ }^{3}$ \\ ${ }^{1}$ Department of Bioengineering, National Institute of Technology Agartala, Agartala-799046, India \\ ${ }^{2}$ Department of Civil Engineering, National Institute of Technology Agartala, Agartala-799046, India \\ ${ }^{3}$ Department of Chemical Engineering, National Institute of Technology Agartala, Agartala-799046, \\ India
}

Corresponding author: ${ }^{\bowtie}$ payell.moon12@gmail.com

Received: July 3, 2021; Accepted: August 12, 2021; Published: August 24, 2021

\begin{abstract}
To investigate the performance of microbial fuel cell (MFC) with a single-chamber membrane, Pseudomonas aeruginosa is used as a biocatalyst for various synthetic wastewaters rich in carbohydrate and is compared with real dairy wastewater in this experiment. Therefore, the choice of appropriate carbon, nitrogen, $\mathrm{NaCl}$, inoculum content, temperature, and $\mathrm{pH}$ process parameters used for preparing synthetic wastewater was agreed upon by one-variable-at-a time approach. Maximum level of voltage generation attained from the synthetic wastewater was $485 \mathrm{mV}$ when supplemented with $1.5 \%$ of lactose as a source of carbon, $0.3 \%$ of ammonium chloride as a decent nitrogen source, $0.03 \%$ of $\mathrm{NaCl}$, inoculum concentration of $3 \%$, the temperature at $37^{\circ} \mathrm{C}$ and $\mathrm{pH}$ 7. On the other hand, the maximum voltage attained with real dairy wastewater was $561 \mathrm{mV}$ with high chemical oxygen demand (COD) value of $801 \mathrm{mg} \mathrm{l}^{-1}$. The maximum power density obtained from dairy wastewater was $73.54 \mathrm{~mW} \mathrm{~m}^{-2}$. High voltage achieved for MFC operating with real dairy wastewater suggests that it can be used not only for the industrial application to generate more renewable power, but also for the wastewater treatment carried out at the same time.
\end{abstract}

Keywords

Green technology; microbial fuel cell; voltage generation; synthetic wastewater; dairy wastewater.

\section{Introduction}

In current years, an expanding emphasis is put on inexhaustible energy sources, which are substantially biodegradable, can't be depleted, and preserve the valuable conventional power 
sources like coal, oil, and petrol [1]. In previous couple of decades, however, people had consistently used non-renewable energy sources and utilized them for power generation [2]. As they belong to the conventional sources of energy, they are exhaustible [3] and are getting depleted at an alarming rate. Thus, a significant number of petroleum derivatives may never be accessible in only a couple of years. Henceforth some additional energy sources for the nourishment of the present advancement have to be discovered [4]. Among them, microbial fuel cell technology is gaining more attention for industrial applications and attaining more power at a large scale [5]. The utility of the energy from microbial fuel cells (MFC) is significant to keep attention on their production [6]. Therefore, the performance of MFC can be increased by changing the physicochemical parameters and these days, research with MFC is also achieving more attention [7].

There is no common medium for the generation of voltage with microorganisms [8], because specific physicochemical parameters and nourishment are necessary for growth and voltage generation by microorganisms [9]. Thus, perfect process optimization is vital for the reduction of handling costs.

The present paper describes preparation of the synthetic wastewater media for voltage generation. As per previous reports, there is no sole information on the synthetic wastewater preparation under dissimilar types of process parameters and a comparison with real wastewater from the dairy industry was never performed. The experiments were carried out with synthetic wastewater and dairy wastewater as a substrate to check the performance of MFC for advanced renewable power generation [10]. The experiments conducted for power generation from wastewater contribute to green technology by reducing the extent of carbon dioxide and other gases which cause global warming [11].

Preparing a synthetic wastewater media for voltage generation needs a proper assortment of carbon sources, nitrogen sources, and salts at first. Then, nutritional necessity can be enhanced by the statistical methods. One-variable-at-a time methodology might be beneficial for defining essential inhibitory or stimulation variables before conducting statistical methods. At first, optimizing process parameters for the maximum voltage generation from the synthetic wastewater in a single chamber MFC is carried out, and the maximum output voltage with the optimized values is reported in this paper. Secondly, the same single-chamber MFC operating with real dairy wastewater is carried out, and the maximum voltage obtained is also reported. Finally, the maximum voltage outputs from both the synthetic and dairy wastewater are compared.

\section{Methods}

\section{Chemicals and reagents}

Luria-Bertani broth (Himedia, India), glucose, fructose, lactose, maltose, sucrose, starch (Himedia, India), sodium chloride (Merck, India), ammonium chloride, soyabean meal, sodium nitrate, ammonium sulphate, potassium nitrate (Himedia, India), potassium dihydrogen phosphate (Himedia, India), and di-potassium hydrogen phosphate anhydrous (Himedia, India), were acquired for the experiment. Other chemicals required in this experiment were of analytical grade $[12,13]$.

\section{Microorganism}

The Pseudomonas aeruginosa, which is an exoelectrogenic bacteria was taken from the bioengineering lab of NIT Agartala, India. Luria-Bertani broth and Agar (LBA) media were used as maintenance media for sub-culturing and $\mathrm{pH}$ of media was kept at 7.4 before sterilization. After sterilization, LBA media was transferred to the plate and waited for 30 minutes until it became solidified. Pseudomonas aeruginosa were then transferred to solidified media and incubated at 
$37^{\circ} \mathrm{C}$ for 24 hours. The synthetic wastewater was prepared in $200 \mathrm{ml}$ conical flask holding lactose (10 $\left.\mathrm{g} \mathrm{l}^{-1}\right)$, ammonium chloride $\left(0.20 \mathrm{~g} \mathrm{l}^{-1}\right)$, sodium chloride $\left(0.30 \mathrm{~g} \mathrm{l}^{-1}\right)$, dipotassium phosphate $\left(1.26 \mathrm{~g} \mathrm{l}^{-1}\right)$, potassium dihydrogen phosphate $\left(0.42 \mathrm{~g} \mathrm{l}^{-1}\right)$ and trace metals solution (1 $\left.\mathrm{ml}\right)[14,15] .2 \%$ new culture of Pseudomonas aeruginosa optical density at $550 \mathrm{~nm} \approx 0.2$ was inoculated in MFC on the synthetic media at $\mathrm{pH} 7.4$. Individually, various carbon and nitrogen sources were used in the experiments. The dairy wastewater was collected from the local area and further diluted during experiments. The MFC was examined in batch mode each time for 360 hours (15 days).

\section{MFC arrangement and operating processes}

The investigation was run in $300 \mathrm{ml}$ single-chamber MFC of working volume $200 \mathrm{ml}$, and cylindrical reactor made from acrylic resin. The anode and the cathode were carbon-cloth with a surface area of $50 \mathrm{~cm}^{2}$ having cloth thickness $0.37 \mathrm{~mm}$ and a diameter of $50 \mathrm{~mm}$. Carbon cloth cathode was loaded with $0.5 \mathrm{mg} \mathrm{cm}^{-2}$ of Pt. Nafion 117 was used as the membrane. The pipe length was $110 \mathrm{~mm}$ with an outer diameter of $70 \mathrm{~mm}$ and $60 \mathrm{~mm}$. The membrane showed only ionic conductivity of about $0.078 \mathrm{~S} \mathrm{~cm}^{-1}$. The electrodes were kept at a gap of 175 microns, and membrane was placed between electrodes. The electrodes were attached by stainless-steel wires and digital multimeter. The single-chamber MFC and its components are presented in Figure 1.

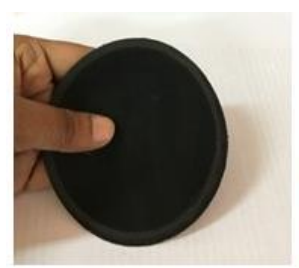

ANODE

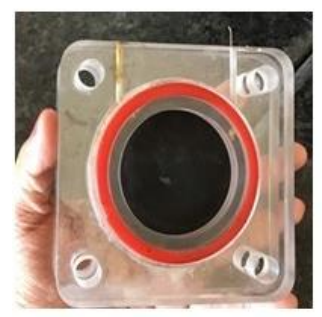

O RING

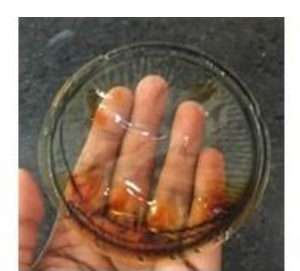

MEMBRANE

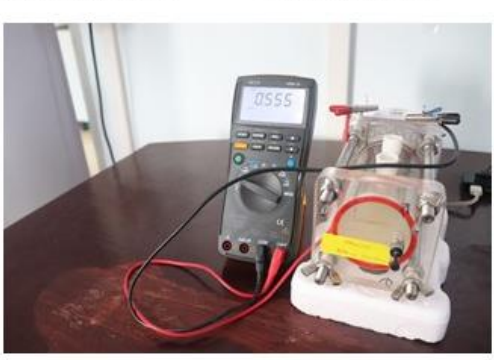

MFC SETUP

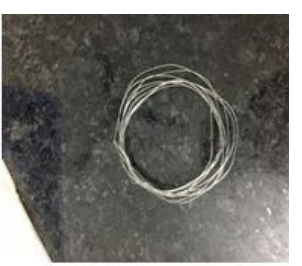

WIRE

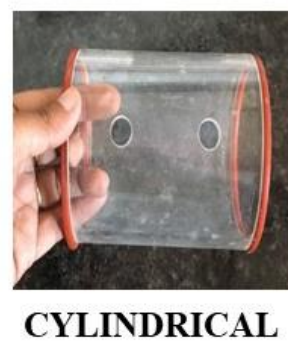

CHAMBER

Figure 1. Single-chamber MFC components and setup

\section{Effects of various process parameters}

The carbon source, nitrogen source, inoculum content, temperature, and $\mathrm{pH}$ were considered as process factors for the acquirement of maximum power generation from the preparing synthetic wastewater. One-variable-at-a time approach was applied to select the values of main factors.

\section{Results and discussion}

Choice of appropriate carbon and nitrogen sources for preparing synthetic wastewater

The lactose was replaced by other carbon sources viz. fructose, glucose, maltose, sucrose, and starch on the base carbon content of $1 \% \mathrm{w} / \mathrm{v}$ [16]. The maximum voltage was obtained in the presence of lactose as a simple carbon source, which gives a reading of $410 \mathrm{mV}$ as open-circuit voltage at digital multimeter and is maximum yield when compared with other selected sources of carbon (Figure 2). The voltages obtained by other carbon sources is presented in Figure 2, showing less encouragement on the voltage generation than lactose [17]. The suppressive effect on such an 
event was witnessed when other carbon sources were examined [18]. Catabolite suppression may be the utmost probable cause for this oppressive outcome $[19,20]$.

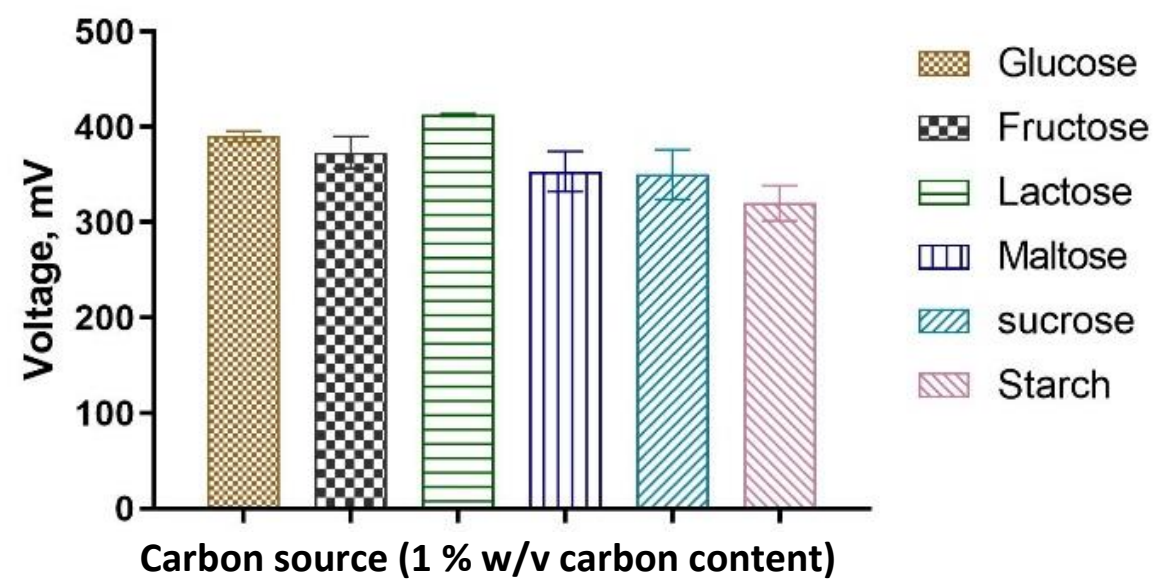

Figure 2. Effect of different carbon sources on voltage generation

It was formerly proven that a catabolite control protein was responsible for this controlling mechanism that transduced signal for enzyme synthesis suppression [21]. In the medium, organic and inorganic nitrogen sources were used, such as ammonium chloride, soybean meal, sodium nitrate, ammonium sulfate, and potassium nitrate based on nitrogen content at $0.2 \% \mathrm{w} / \mathrm{v}[22,23]$. Maximum voltage was attained in the presence of ammonium chloride as a simple nitrogen source, producing $415 \mathrm{mV}$, thus considered maximum yield in assessment among other nitrogen sources as presented in Figure 3.

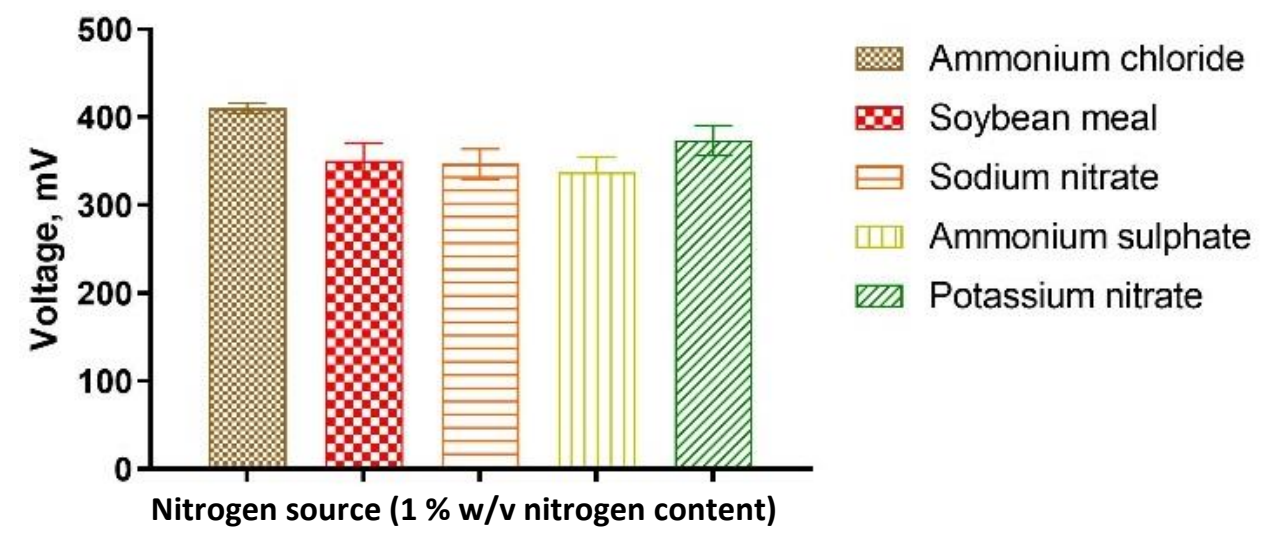

Figure 3. Effect of different nitrogen sources on voltage generation

The selected nitrogen sources presented in Figure 3 significantly affect to voltage generation when matched with ammonium chloride [24]. It is also witnessed that voltage production progresses in the presence of lactose and ammonium chloride. The sources of nitrogen other than ammonium chloride displayed a comparative drop in voltage production [25].

The effect of carbon, nitrogen, $\mathrm{NaCl}$, inoculum content, temperature and $\mathrm{pH}$ on voltage generation

The assessment of voltage generation at dissimilar levels of carbon source (lactose) in the synthetic wastewater media as components is presented in Figure 4.

The outcomes display that the voltage generation is improved with increase of lactose concentration from 0.5 to $1.5 \%$. Hence, the upper level of lactose harms voltage generation, as presented in Figure 4. The voltage upsurges with a rise in ammonium chloride concentration in the media up to $0.3 \%$. However, above concentration of $0.3 \%$, voltage generation is declined (Figure 5 ). 


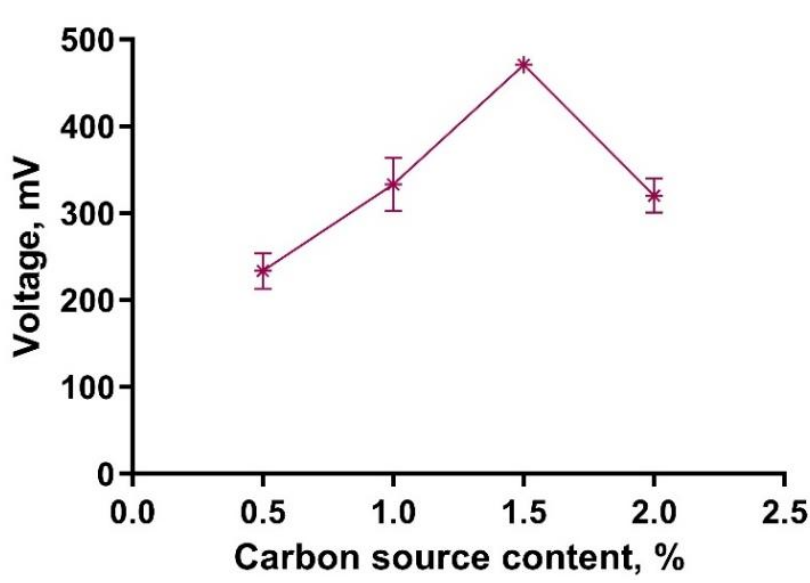

Figure 4. Effect of carbon content (lactose) on voltage generation

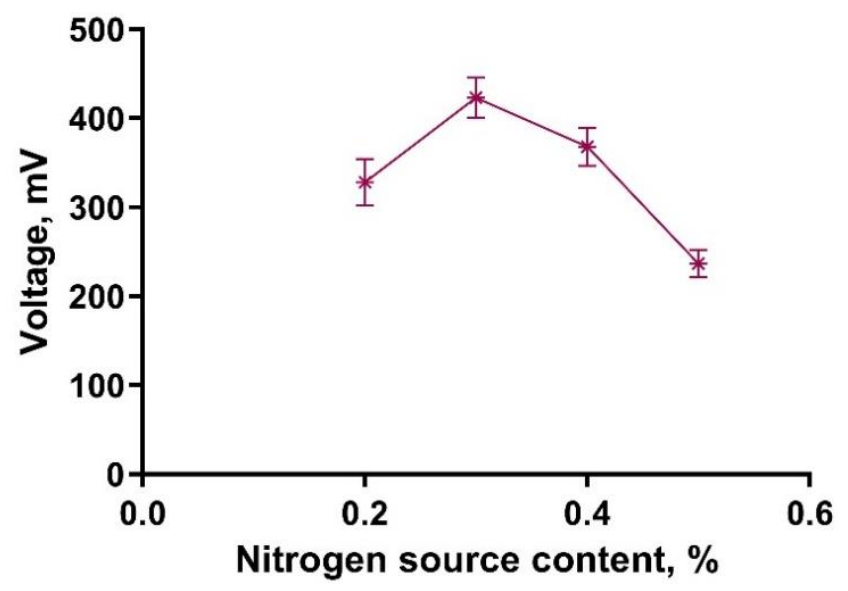

Figure 5. Effect of nitrogen content (ammonium chloride) on voltage generation

Voltage generation was improved by adding sodium chloride media from 0.02 to $0.04 \%$. The voltage generation at $0.03 \%$ of $\mathrm{NaCl}$ was observed to achieve the highest voltage, while at higher sodium chloride content, the generated voltage declined (Figure 6).

Moreover, sodium chloride acts as an inducer for voltage generation. It was shown previously that microbes utilize sodium-driven solute carriage systems for their existence and adjustment in high pH environments [26-28]. Hence sodium ions are compulsory for bioenergetics and metabolic courses of bacterium such as $\mathrm{pH}$ homeostasis and ATP synthesis [29].

After the effective media optimization, the remaining physical and chemical process parameters were improved considering the optimized medium. The assessment of voltage generated by the impact of dissimilar levels of main physical and chemical factors is presented in Figures 7, 8 and 9.

Voltage generation upswung with rise of inoculum content from 1 to $3 \%$, and from the maximum at $3 \%$ of inoculum concentration, the value of voltage started to decrease (Figure 7).

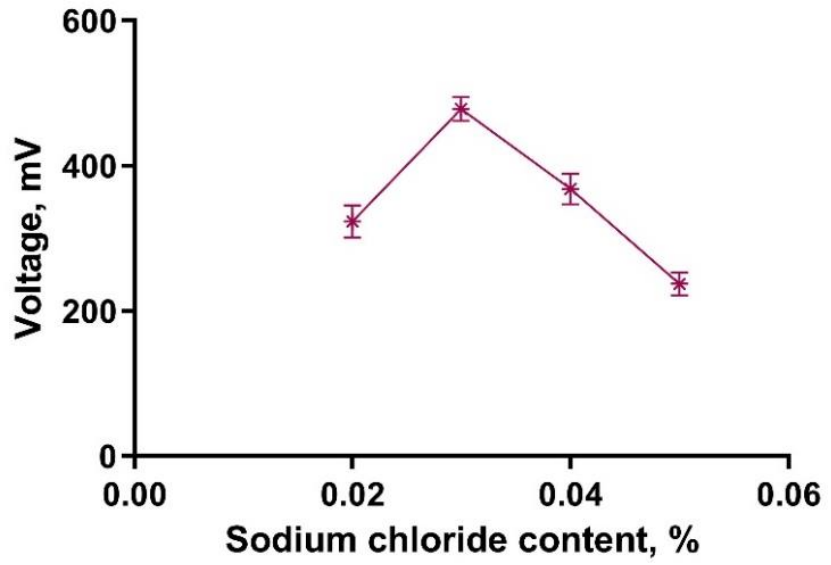

Figure 6. Effect of sodium chloride content on voltage generation

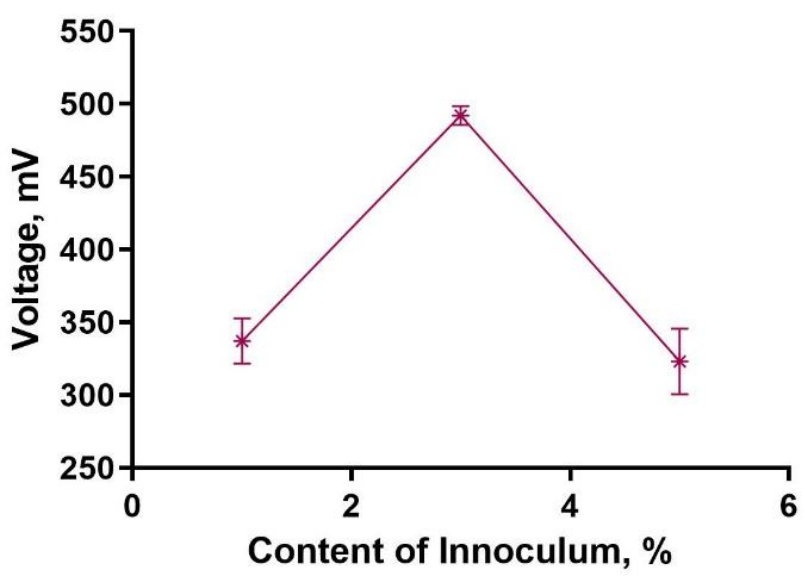

Figure 7. Effect of inoculum content on voltage generation.

This may occur due to the restriction of other medium components, which cause a decrease in voltage generation [30]. On the other side, in the case of temperature, it was observed that voltage increases with an increase of temperature from 30 to $37^{\circ} \mathrm{C}$ (Figure 8).

The obtained results specify that the voltage generation is stimulated by temperature. The voltage generation decreases at lower temperature, what is due to the inactivation of enzymes and ribosomes which are directly or indirectly responsible for the growth of the cell [31]. At the same time, it means 
that at temperatures higher than $37^{\circ} \mathrm{C}$, the volatility of membranes can change, which in turn alters the carriage movement of compounds that are soluble [32]. Thus, the highest voltage generation was obtained at $37^{\circ} \mathrm{C}$. Voltage generation was progressively improved from $\mathrm{pH} 6$ to $\mathrm{pH}$ 7, but beyond $\mathrm{pH}$ 7 , radical reduction of protease production was obtained and presented in Figure 9.

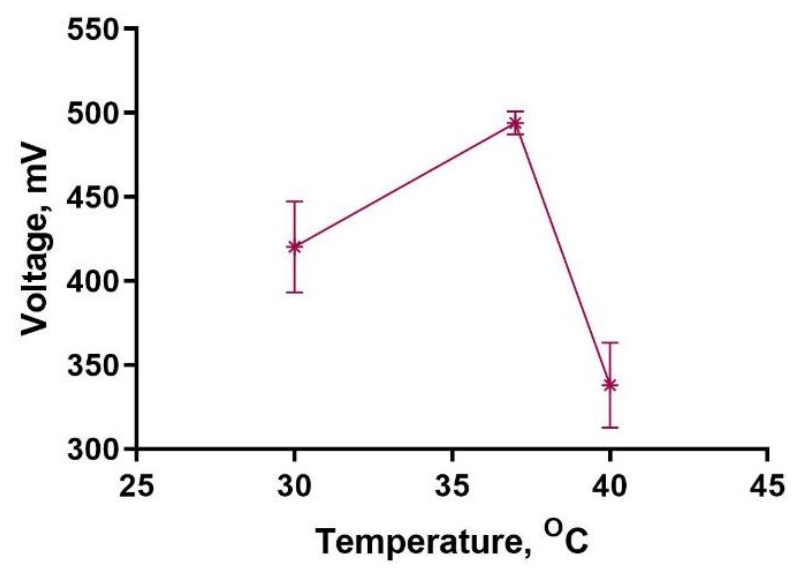

Figure 8. Effect of temperature on voltage generation.

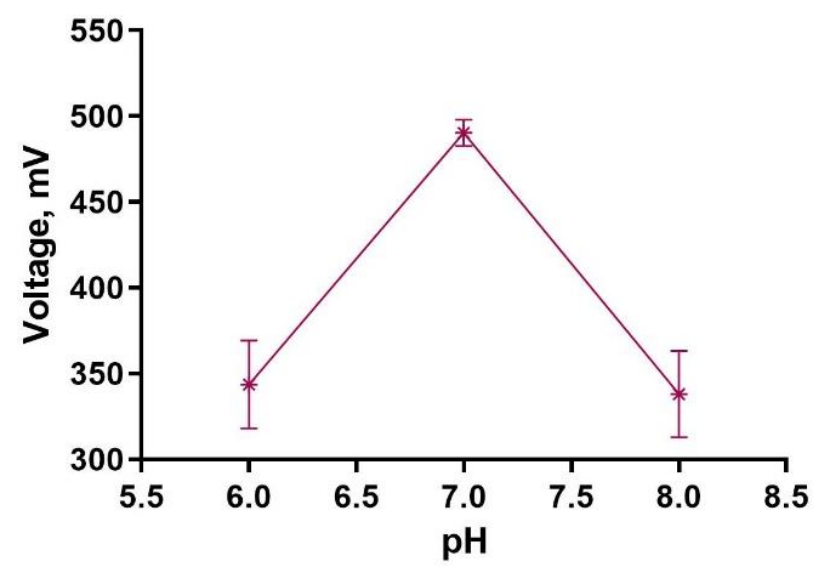

Figure 9. Effect of $\mathrm{pH}$ on voltage generation

Thus, the optimum $\mathrm{pH}$ value for the generation of voltage is 7. The inactivation of the enzyme at higher $\mathrm{pH}$ is straight or incidentally responsible for the cell growth, which in turn reduces the voltage [33]. Thus, the catalytic action of these enzymes is governed by $\mathrm{pH}$ of the medium. Hence, the alteration in the media $\mathrm{pH}$ is mainly responsible for the variation in the rate of reaction [34].

\section{Voltage generation with synthetic wastewater}

The maximum voltage generation of $485 \mathrm{mV}$ was obtained with synthetic wastewater having lactose of $1.5 \%$, ammonium chloride of $0.3 \%, 0.03 \%$ of $\mathrm{NaCl}$, inoculum content of $3 \%$, the temperature at $37^{\circ} \mathrm{C}$ and $\mathrm{pH} 7$ after 360 hours of experiment in the single-chamber MFC (Figure 10).

a

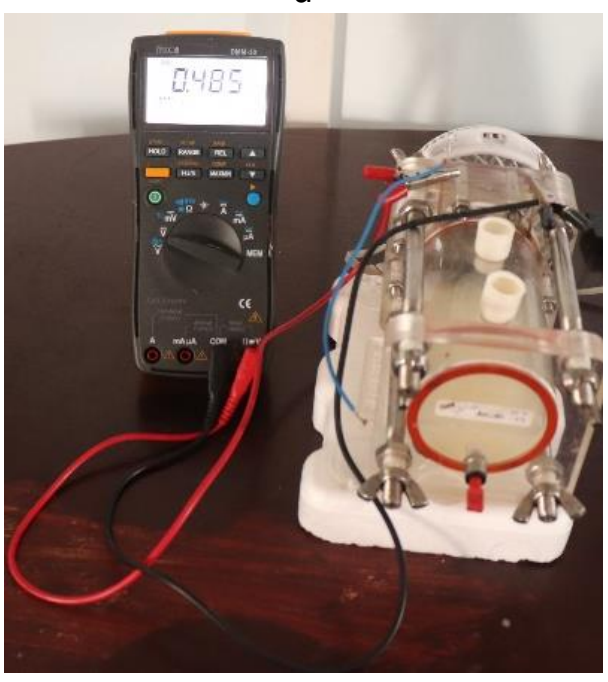

b

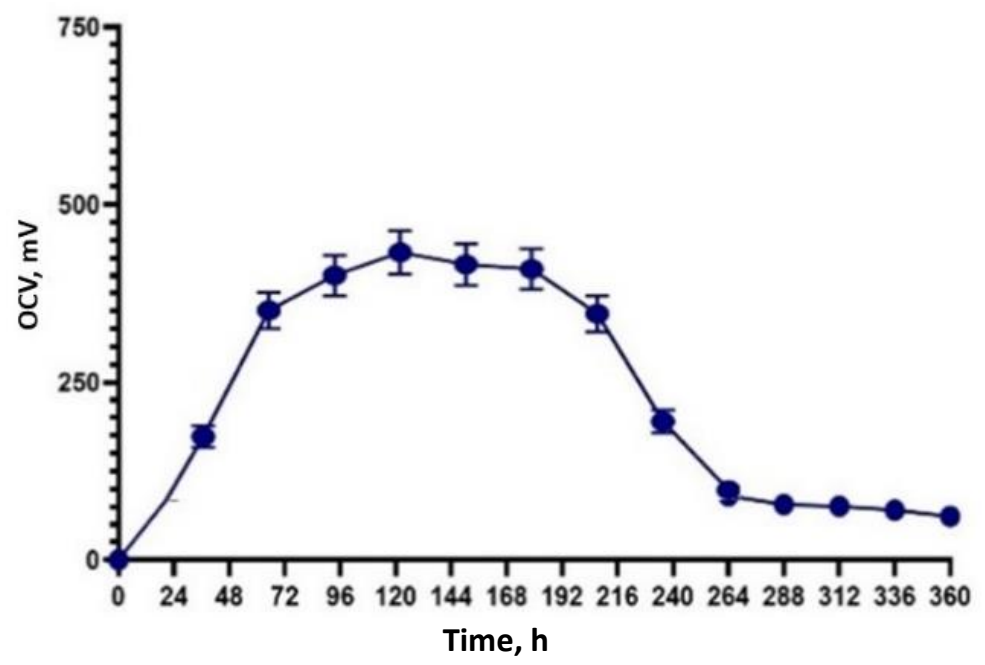

Figure 10. (a) Maximum voltage reached in batch operation of MFC with synthetic wastewater; (b) voltage vs. time in batch operation of MFC with synthetic wastewater

Voltage generation with real dairy wastewater

Since real dairy wastewater comprises several organic matters with high chemical oxygen demand (COD) value of $8010 \mathrm{mg} \mathrm{l}^{-1}$, the probable influence was conveyed for open circuit voltage 
(OCV) observation by running a batch process for 360 hours (15 days) [35]. Therefore a full batch operation was carried out with real dairy wastewater to understand the practicality of OCV generation in single-chamber MFC [36,37]. The value of COD of real dairy wastewater was adjusted at $10 \mathrm{mg} \mathrm{l}^{-1}$ and $\mathrm{pH}$ to 7 , and MFC was operated at the temperature of $37{ }^{\circ} \mathrm{C}$ for 360 hours (15 days) [38]. According to Figure 11 (a), maximum OCV of $561 \mathrm{mV}$ was reached using real dairy wastewater. It is also marked from Figure $11(\mathrm{~b})$, that OCV is progressively increasing during 48 hours of operation, reached $573 \mathrm{~V}$ at 120 hours, and remained constant for 168 hours. After that, OCV is gradually declining by duration of the process [39].

Former studies showed that natural dairy wastewater is considered as the most efficient substrate for MFC to produce renewable energy [40].

a

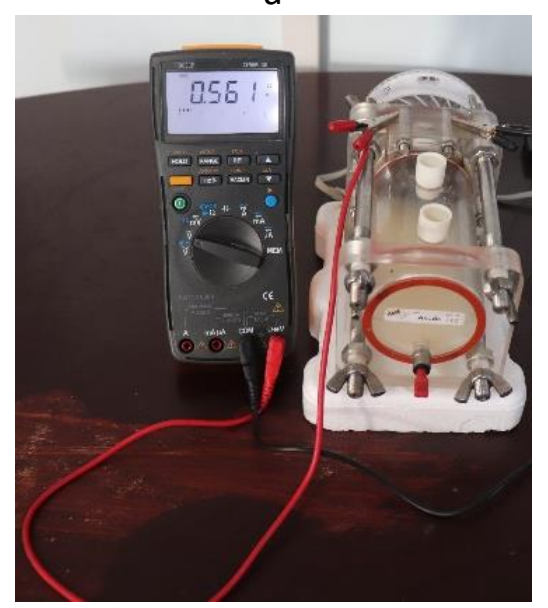

b

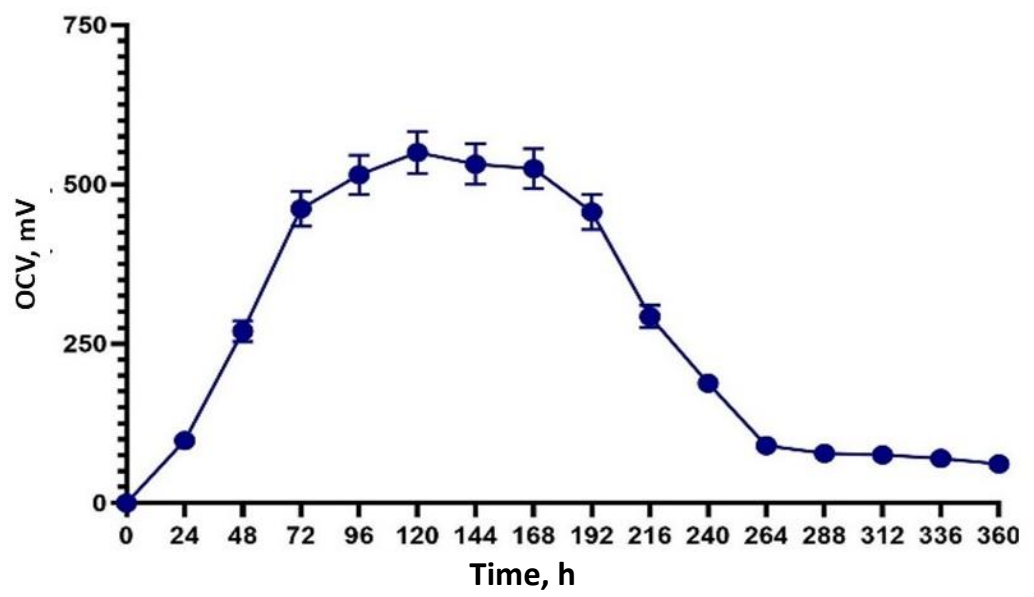

Figure 11. (a) Maximum voltage reached in batch operation of MFC with real dairy wastewater; (b) voltage vs. time in batch operation of MFC with real dairy wastewater

From the above experimental output, we can say that wastewater from the dairy industry contains a higher amount of lactose related to synthetic wastewater, as the output voltage is higher with real dairy wastewater. So, scientists and scholars need to put more attention towards the application of wastewater from organic matter to attain products with added value [41].

In the single-chamber MFC reactor, both energy production and wastewater treatment processes were provided from single section fuel cells without the need of any mediator, as exoelectrogenic bacteria Pseudomonas aeruginosa were used [42].

The main challenge in the fuel cell is to reduce the internal resistance of the system. As in an MFC, there are no rotating parts, so the main contribution of the total resistance in MFC is the internal resistance caused by the substrate. Thus, if the internal resistance of the system was reduced, more electrons from the organic substrate would be transferred and more power produced [43]. Therefore, understanding the origins of internal resistance in MFC seems to be important.

In the following experiment with dairy wastewater, the external resistance was varied from 50 to $15000 \Omega$, and the gained voltages were plotted vs. current density to achieve the polarization curve. At the same graph, the power density obtained from the product of current density and voltage was plotted against current density to achieve the power density curve shown in Figure 12. Remarkably, three different phases - phase-I, phase-II, and phase III are evident in the polarization curve [44]. It is clear from phase I of the polarization curve that rapidly reduced voltage is due to the transfer of charges initially, which contributes to the system resistance. This internal resistance can be minimized by increasing the surface area of the anode, using a mediator in the substrate for 
better transmission of electrons, and increasing of temperature [45]. Secondly, in phase-II, the constant drop of voltage is observed due to the solvent resistance, resistance present in the material used for connecting electrodes, and resistance caused by the membrane. All these resistances contribute to the increase in internal resistance, which can be reduced using a buffer in the system, low resistance wires, and highly conductive proton exchange membrane [46]. At last, the phase-III causes the sudden reduction of voltage at high current density due to activation of biochemical reaction, the energy requirement for metabolism during bacterial growth, and restriction of mass transport inside MFC. In this case, the internal resistance can be limited by a suitable membrane [47]. Therefore, from phase-II of the polarization graph, the developed internal resistance of MFC can be measured. In the above experiment with dairy wastewater, $760 \Omega$ of internal resistance is obtained during batch operation of MFC.

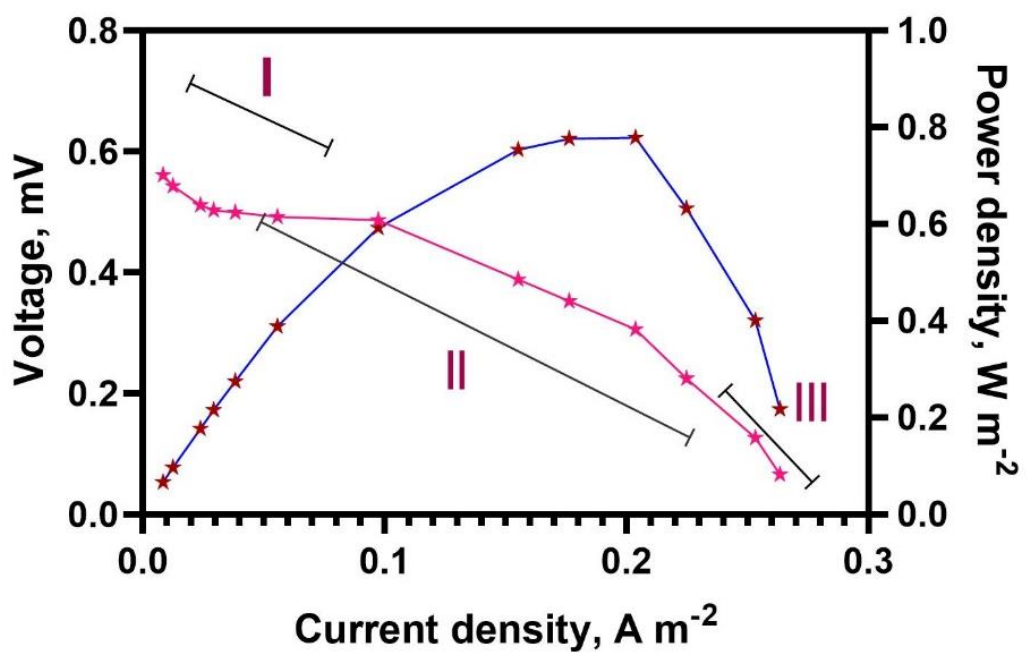

Figure 12. Polarization and power density graphs

As shown in Figure 12, the power density curve firstly increases with the increase of current density up to $73.54 \mathrm{~mW} \mathrm{~m}^{-2}$, and then decreases with the additional increase of current density. Christwardana et al. [48] reported that the maximum power density of seawater, lake water, and tap water is about 21.92, 4.69, and $11.79 \mathrm{~mW} \mathrm{~m}^{-2}$, respectively, which is all much less than our experimental power density of $73.54 \mathrm{~mW} \mathrm{~m}^{-2}$ obtained from dairy wastewater. The maximum power density was attained at $0.364 \mathrm{~V}$, with the maximum current density of $295 \mathrm{~mA} \mathrm{~m}^{-2}$. Arulmani et al. [50] reported the maximum current density of $185.23 \pm 15.10$ (P1) and $291.23 \pm 7.50 \mathrm{~mA} \mathrm{~m}^{-2}$ (P2) with bio-slurry, which is less, compared to our current density. The optimum level of cell voltage can be anticipated from the junction point where the polarization and power density curve intersect, i.e. $0.539 \mathrm{~V}$. The present investigation clearly showed that comparatively higher power density and current density can be attained using real dairy wastewater [49].

\section{Conclusion}

The conducted experiments showed that the MFC batch process is an active procedure for the workable generation of sustainable power by exoelectrogenic bacteria (Pseudomonas aeruginosa). The batch process examined for 360 hours (15 days) with one-variable-at-a-time optimized synthetic wastewater media containing lactose of $1.5 \%$, ammonium chloride of $0.3 \%, 0.03 \%$ of $\mathrm{NaCl}$, inoculum concentration of $3 \%$, temperature at $37^{\circ} \mathrm{C}$ and $\mathrm{pH} \mathrm{7,} \mathrm{generated} \mathrm{OCV} \mathrm{of} 485 \mathrm{mV}$. Secondly, the experiment was carried with real dairy wastewater containing organic compounds, and the batch process of MCF generated OCV of $561 \mathrm{mV}$. The maximum power density and current density 
obtained from dairy wastewater were $73.54 \mathrm{~mW} \mathrm{~m}^{-2}$ and $295 \mathrm{~mA} \mathrm{~m}^{-2}$. This experiment pointed to the workable methodology for removing environmental pollutants using bioreactor (MFC), which thus provides an added value to its ordinary power generation.

Acknowledgments: All authors expressed gratefulness to the honorable Director, NIT Agartala, for endless support and encouragement for creating a research environment at Institute. Payel Choudhury acknowledges CSIR, Government of India, for research fellowship with ACK No. (3431392/2K19/1).

\section{References}

[1] A. T. Hoang, V. V. Pham, X. P. Nguyen, Journal of Cleaner Production 305 (2021) 127161. https://doi.org/10.1016/i.jclepro.2021.127161

[2] C. Koroneos, T. Spachos, N. Moussiopoulos, Renewable Energy 28(2) (2003) 295-310. https://doi.org/10.1016/S0960-1481(01)00125-2

[3] A. Adesina, P. Awoyera, Utilization of Biomass Energy in Cement Production: A Pathway Towards Sustainable Infrastructure, in Renewable Energy and Sustainable Buildings. Innovative Renewable Energy, A. Savigh (Ed.), Springer, Cambridge, UK, 2020, p 791. https://doi.org/10.1007/978-3-030-18488-9 65

[4] S. E. Hosseini, M. A. Wahid, International Journal of Energy Research 44(6) (2020) 4110 4131. https://doi.org/10.1002/er.4930

[5] S. Z. Abbas, M. Rafatullah, N. Ismail, R. A Nastro, International Journal of Energy Research 41(14) (2017) 2345-2355. https://doi.org/10.1002/er.3804

[6] S. Z. Abbas, M. Rafatullah, N. Ismail, F. R. Shakoori, RSC Advances 8(34) (2018) 1880018813. https://doi.org/10.1039/c8ra01711e

[7] S. Z. Abbas, M. Rafatullah, N. Ismail, M. I. Syakir, International Journal of Energy Research 41(9) (2017) 1242-1264. https://doi.org/10.1002/er.3706

[8] P. Choudhury, B. Bhunia, T. K. Bandyopadhyay, Journal of Electrochemical Science and Engineering 11(2) (2021) 129-142. https://doi.org/10.5599/jese.924

[9] S. Shahane, P. Choudhury, O. Tiwari, U. Mishra, B. Bhunia, Exoelectrogenic Bacteria: A Candidate for Sustainable Bio-electricity Generation in Microbial Fuel Cells, in Waste to Sustainable Energy, L. Singh, D. M. Mahapatra (Eds.), CRC Press, Boca Raton, USA, 2019. p. 106. https://doi.org/10.1201/9780429448799

[10] S. Z. Abbas, M. Rafatullah, M. A. Khan, M. R. Siddiqui, Frontiers in Microbiology 9 (2019) 3348. https://doi.org/10.3389/fmicb.2018.03348

[11] A. Gatto, F. Busato, Journal of Cleaner Production 253 (2020) 118691. https://doi.org/ 10.1016/i.jclepro.2019.118691

[12] B. Balannec, M. Vourch, M. Rabiller-Baudry, B. Chaufer, Separation and Purification Technology 42(2) (2005) 195-200. https://doi.org/10.1016/i.seppur.2004.07.013

[13] K. Bensadok, N. El Hanafi, F. Lapicque, Desalination 280(1-3) (2011) 244-251. https://doi.org/10.1016/i.desal.2011.07.006

[14] P. Choudhury, R. N. Ray, T. K. Bandyopadhyay, International Journal of Renewable Energy Technology 9(1-2) (2018) 191-197. https://doi.org/10.1504/IJRET.2018.090114

[15] P. Choudhury, R. N. Ray, T. K. Bandyopadhyay, O. N. Tiwari, B. Bhunia, International Journal of Hydrogen Energy 46(31) (2021) 16815-16822. https://doi.org/10.1016/j.ijhydene.2020. $\underline{08.024}$

[16] B. Bhunia, B. Basak, P. Bhattacharya, A. Dey, Journal of Bioscience and Bioengineering 115(1) (2013) 86-89. https://doi.org/10.1016/j.jbiosc.2012.08.003

[17] P. Choudhury, R. N. Ray, T.K. Bandyopadhyay, B. Bhunia, Fuel 266 (2020) 117073. https://doi.org/10.1016/i.fuel.2020.117073 
[18] Y.-J. Choi, E.-K. Jung, H.-J. Park, S.-H. Jung, S.-H. Kim, Bulletin of the Korean Chemical Society 28(9) (2007) 1591-1594. https://doi.org/10.5012/bkcs.2007.28.9.1591

[19] F. G. Priest, Bacteriological Reviews 41(3) (1977) 711-753.

[20] C. G. Kumar, R. K. Malik, M. P. Tiwari, K. D. Jany, MAN Microbiologie, aliments, nutrition 17(1) (1999) 39-48. http://pascal-francis.inist.fr/vibad/index.php?action=getRecordDetail \&idt $=1944601$

[21] S. Tobisch, D. Zühlke, J. Bernhardt, J. Stülke, M. Hecker, Journal of Bacteriology 181(22) (1999) 6996-7004. https://doi.org/10.1128/JB.181.22.6996-7004.1999

[22] B. Chauhan, R. Gupta, Process Biochemistry 39(12) (2004) 2115-2122. https://doi.org/ 10.1016/i.procbio.2003.11.002

[23] S. Puri, Q. K. Beg, R. Gupta, Current Microbiology 44(4) (2002) 286-290. https://doi.org/10. 1007/s00284-001-0006-8

[24] O. Lefebvre, Z. Tan, S. Kharkwal, H. Y. Ng, Bioresource Technology 112 (2012) 336-340. https://doi.org/10.1016/i.biortech.2012.02.048

[25] S. Malathi, R. Chakraborty, Applied and Environmental Microbiology 57(3) (1991) 712-716. https://doi.org/10.1128/aem.57.3.712-716.1991

[26] T. A. Krulwich, A. A. Guffanti, Journal of Bioenergetics and Biomembranes 21(6) (1989) 663677. https://doi.org/10.1007/BF00762685

[27] S. G. Prowe, J. L. van de Vossenberg, A. J. Driessen, G. Antranikian, W. N. Konings, Journal of Bacteriology 178(14) (1996) 4099-5104. https://doi.org/10.1128/ib.178.14.4099-4104.1996

[28] T. A. Krulwich, The Journal of Membrane Biology 89 (1986) 113-125. https://doi.org/10. 1007/BF01869707

[29] C. J. Peddie, G. M. Cook, H. W. Morgan, Journal of Bacteriology 181(10) (1999) 3172-3177. https://doi.org/10.1128/JB.181.10.3172-3177.1999

[30] G. S. Lakshmi, C. S. Rao, R. S. Rao, P. J. Hobbs, R. S. Prakasham, Biochemical Engineering Journal 48(1) (2009) 51-57. https://doi.org/10.1016/i.bej.2009.08.005

[31] B. Min, Ó. B. Román, I. Angelidaki, Biotechnology Letters 30(7) (2008) 1213-1218. https://doi.org/10.1007/s10529-008-9687-4

[32] M. Phisalaphong, N. Srirattana, W. Tanthapanichakoon, Biochemical Engineering Journal 28(1) (2006) 36-43. https://doi.org/10.1016/i.bej.2005.08.039

[33] M.L. Shuler, F. Kargi, Bioprocess Engineering: Basic Concepts 2008. 155-200.

[34] Y. Ren, Y. Lv, Y. Wang, X.J.C. Li, Chemosphere 257 (2020) 127251. https://doi.org/10.1016/ j.chemosphere.2020.127251

[35] M. M. H. Coelho, N. W. S. Morais, E. L. Pereira, R. C. Leitão, A. B. dos Santos, Biochemical Engineering Journal 156 (2020) 107502. https://doi.org/10.1016/j.bej.2020.107502

[36] M. K. Alavijeh, S. Yaghmaei, M. M. Mardanpour, Bioelectrochemistry 106(B) (2015) 298307. https://doi.org/10.1016/i.bioelechem.2015.07.003

[37] X.-W. Liu, Y.-P. Wang, Y.-X. Huang, X.-F. Sun, G.-P. Sheng, R.J. Zeng, F. Li, F. Dong, S.-G. Wang, Z.-H. Tong, H.-Q. Yu, Biotechnology and Bioengineering 108(6) (2011) 1260-1267. https://doi.org/10.1002/bit.23056

[38] M. M. Mardanpour, M. N. Esfahany, T. Behzad, R. Sedaqatvand, Biosensors and Bioelectronics 38(1) (2012) 264-269. https://doi.org/10.1016/i.bios.2012.05.046

[39] A. Callegari, D. Cecconet, D. Molognoni, A. G. Capodaglio, Journal of Cleaner Production 189 (2018) 563-569. https://doi.org/10.1016/i.jclepro.2018.04.129

[40] P. Choudhury, R. N. Ray, T. K. Bandyopadhyay, B. Basak, M. Muthuraj, B. Bhunia, International Journal of Hydrogen Energy 46(4) (2021) 3171-3182. https://doi.org/10.1016/ j.ijhydene.2020.06.152

[41] S. Sanjay, T. Udayashankara, Materials Today: Proceedings 35(3) (2021) 308-311. https://doi.org/10.1016/i.matpr.2020.01.533 
[42] O. M. Ajunwa, O. A. Odeniyi, E. O. Garuba, E. Marsili, Process Biochemistry 104 (2021) 2738. https://doi.org/10.1016/i.procbio.2021.01.003

[43] B. Kim, I. S. Chang, R. M. Dinsdale, A. J. Guwy, Electrochimica Acta 366 (2021) 137388. https://doi.org/10.1016/i.electacta.2020.137388

[44] T. Karuppiah, U. Uthirakrishnan, S. V. Sivakumar, S. Authilingam, J. Arun, R. Sivaramakrishnan, A. Pugazhendhi, International Journal of Hydrogen Energy (2021) in press. https://doi.org/10.1016/j.ijhydene.2021.06.034

[45] S. Bagchi, R. N. Sahoo, M. Behera, P. Research, Environmental Science and Pollution Research (2021). https://doi.org/10.1007/s11356-021-14940-0

[46] Z. A. Al-Taie, M. S. Shihab, S. Allami, Al-Nahrain Journal of Science 24(2) (2021) 9-13. http://5.10.230.12/index.php/anjs/article/view/2391

[47] M. Sabri, N. Shamsuddin, M. Alias, H. Tajaruddin, M. Z. Makhtar, IOP Conference Series: Earth and Environmental Science 765 (2021) 012060. https://doi.org/10.1088/1755$1315 / 765 / 1 / 012060$

[48] M. Christwardana, L. A. Yoshi, I. Setyonadi, M. R. Maulana, AIP Conference Proceedings 2342(1) (2021) 050001. https://doi.org/10.1063/5.0045395

[49] S. Kataki, S. Chatterjee, M. Vairale, S. Sharma, S. Dwivedi, D. K. Gupta, Renewable and Sustainable Energy Reviews 148 (2021) 111261. https://doi.org/10.1016/i.rser.2021.111261

[50] S. R. B. Arulmani, H. L. Gnanamuthu, S. Kandasamy, G. Govindarajan, M. Alsehli, A. Elfasakhany, A. Pugazhendhi, H. Zhang, Process Biochemistry 107 (2021) 27-37. https://doi.org/10.1016/j.procbio.2021.04.015

(C)2021 by the authors; licensee IAPC, Zagreb, Croatia. This article is an open-access article distributed under the terms and conditions of the Creative Commons Attribution license (https://creativecommons.org/licenses/by/4.0/) 